\title{
American Tariffs and their Impact in the EU and Spain
}

\section{Los aranceles estadounidenses y su impacto en la UE y España}

\author{
Fatima El Khatabi \\ Universidad Autónoma de Madrid \\ Carlos Llano \\ Julián Pérez \\ L. R. Klein Institute \& CEPREDE \\ Universidad Autónoma de Madrid \\ Federico Steinberg \\ Real Instituto Elcano \\ Universidad Autónoma de Madrid
}

\begin{abstract}
Donald Trump's so called trade wars and the COVID-19 pandemic are likely to have a substantial impact on international trade flows and would probably reshape globalization. As trade is restricted by tariffs, global value chains are shortened and international cooperation becomes more difficult, there is a chance that environmental sustainability will increase due to lower and shorter trade flows. This paper tackles this issue by exploring the impact that recent American tariffs have had on the EU with a special focus in Spain. Using the SMART simulation model developed by the World Bank and the UNCTAD, we estimate the impact of the new tariffs applied to iron, steel and aluminum, the products included in the list of products affected by the Airbus dispute, as well as the potential new tariffs to the automotive sector. We end with a discussion on the effects of this new wave of protectionism on sustainability.
\end{abstract}

Keywords: trade policy, protectionism, trade war, Europe, Spain.

JEL Classification: F13, F14, R15

\section{Resumen}

Es probable que las denominadas guerras comerciales de Donald Trump y la pandemia del COVID-19 tengan un impacto sustancial en los flujos comerciales internacionales y acaben por afectar al proceso de la globalización. A medida que el comercio se ve restringido por los aranceles, se acortan las cadenas de valor mundiales y la cooperación internacional se hace más difícil. Sin que sea tampoco evidente, es posible que la sostenibilidad medioambiental pueda beneficiarse de este acortamiento de los flujos comerciales mundiales. Desde una óptica más humilde, este artículo pretende analizar las repercusiones que los recientes aranceles estadounidenses han tenido en la UE, con un enfoque especial en España. Utilizando el modelo de simulación SMART 
desarrollado por el Banco Mundial y la UNCTAD, estimamos el impacto de los nuevos aranceles aplicados al hierro, al acero y al aluminio, la lista de productos afectados por la reciente resolución de la OMC en relación a la «disputa de Airbus», así como los posibles nuevos aranceles para el sector de la automoción. Finalizamos con un debate sobre los efectos que podría ocasionar esta nueva ola de proteccionismo en la sostenibilidad medioambiental.

Palabras clave: política comercial, proteccionismo, guerra comercial, Europa, España

Clasificación JEL: F13, F14, R15

\section{Introduction}

Globalization and the expansion of international trade and investment accelerated after the fall of the Soviet Bloc under US leadership. In fact, in the last decades, the world economy has been experiencing an era of hyper-globalization (Rodrik, 2018a) that seemed uncontested in the surface, but that slowly eroded trust and public support for the so-called liberal world order in the advanced countries due, in part, to sharp increases in inequality and the perceptions that the gains from trade were unequally distributed. This social and political discontent crystalized after the global financial crisis of 2008 and the subsequent recession and led to the election of political leaders that openly opposed free trade and globalization (Otero-Iglesias \& Steinberg, 2017; Rodrik, 2018b).

US President Donald Trump, elected in 2016, was the most consequential of these leaders. His so-called "trade wars", his attacks on the World Trade Organization (WTO) and his preference for bilateral economic negotiations, thus neglecting multilateralism and global governance, translated in trade restrictions and undermined international cooperation.

However, in the middle of these economic and geopolitical tensions, the COVID-19 pandemic struck, putting, in the words of Carmen Reinhart, the Chief Economist of the World Bank "the last nail in the coffin of globalization" (Ward, 2020).

It is still early to know the long-term impact of the pandemic on international trade and globalization. The WTO estimates that international trade flows could fall up to $32 \%$ in 2020 due to the lockdowns and the global recession (World Trade Organization, 2020), the sharpest decline in centuries.

Moreover, several scholars and commentators have suggested that the pandemic might lead to the acceleration of pre-existing global trends that could hamper international trade flows and multilateral economic governance. In particular, trade in manufactured goods could suffer due to a new wave of trade tensions between the US and China, new obstacles to international cooperation, redefinition and nationalization of strategic industries, regionalization of trade flows due to changes in the structure of global value chains, and growing discontent with economic liberalism in general due to the scale of the economic downturn (Mckinsey, 2019; Ortega, 2020; Borrell, 2020; Steinberg, 2020). However, trade in services could well expand due to the acceleration of digital transformation (Baldwin, 2020). 
In sum, it seems that both Trump's tariffs and COVID-19 will lead to a slowdown in substantial parts of globalization and to a transformation of global value chains. This might have a deep negative impact in economic growth, but might well contribute to the fight against climate change and the achievement of the Sustainable Development Goals due to a reduction in greenhouse gas emissions (United Nations, 2020).

Within this context, this paper explores the impact that the tariffs imposed (and announced but not yet implemented) by the Trump Administration since 2017 might have on the EU and Spain. Specifically, we use a partial equilibrium model (SMART) to estimate the impact of the new tariffs applied to the metal sector (iron, steel and aluminum), the products included in the list of products affected by the BoeingAirbus trade dispute within the WTO, as well as the potential impact of the tariffs announced to the automotive sector.

It is important to remark here, that our empirical application is clearly limited. In addition to the ones corresponding to a partial equilibrium approach, it is not able to address a number of relevant effects considered in the literature. For example, it does not consider the macroeconomic distortion introduced by the uncertainty and its effects over foreign direct investment (FDI) and consumption. It does not consider either the intermediate-demand spillover effects induced in all the other products that use the target products as intermediate inputs for producing other final goods and services. This topic has been addressed in Llano et al. $(2019 ; 2020)$.

In a final section, we discuss how the results obtained here can be linked to the general discussion of this special issue on "Globalization and Sustainability", also bringing some comments about the potential effect of the COVID-19 crisis.

The structure of the rest of the paper is as follows. Next section reviews the main milestones in the protectionism measures announced and adopted by the Trump Administration and their effects on the EU and Spain. Next, we revise the economic theory of the impact of tariffs on exports, and we formulate the mathematical equations used by the SMART simulation model. Then, we provide a descriptive analysis and we explain the main results obtained from our model. The paper concludes with an open discussion linking the protectionism measures analyzed with the current COVID-19 crisis and the leitmotiv of this special issue, the link between globalization and sustainability.

\section{The recent trade war in perspective}

The protectionist spirit Trump exhibited during his 2016 electoral campaign translated into action. In the campaign trial he promised protectionism and in December 4, 2018, he even tweeted "I am a tariff man". So far, he has delivered and US trading partners have retaliated, leading to what has been labeled a "trade war". It all started in January 2018, when the US imposed tariffs on imported washing machines and solar panels. On March, new import tariffs were approved on 'iron 
and steel' and 'aluminum' of $25 \%$ and $10 \%$, respectively, on the questionable bases that they constituted a threat to American national security. At the same time, the US dropped out from the Trans Pacific Partnership (TPP), renegotiated NAFTA (now called USMCA) and the US-South Korea FTA, and started a trade and technological confrontation with China.

Until that point, the EU had only suffered Trump's protectionism in the form of limited steel and aluminum tariffs. However, on May 23 ${ }^{\text {rd }}, 2018$, the Secretary of State for Commerce of the US initiated an investigation pursuant to section 232 of the Trade Expansion Act of 1962 to determine the impact on national security of imports of automobiles, including cars, SUVs, vans and light trucks, and automotive parts. The main targets seemed to be the EU (especially Germany) and Japan. On June 22, 2018, before knowing the results of the investigation, President Trump threatened to impose a $20 \%$ tariff on all imports of vehicles from the EU, also arguing that they were a threat to American national security. In May 2019, Trump established a fragile truce with Japan and the EU through a six-month postponement of new tariffs on vehicle imports from the EU and Japan while negotiating free-trade agreements with both. Moreover, in November 2019, he granted a further extension as he refused to nominate new judges to the Appellate Body of the dispute settlement mechanism of the WTO, thus effectively blocking its effectiveness, which is considered by the $\mathrm{EU}$ as one of the cornerstones of the global trading system.

Despite undermining the WTO, the Trump Administration took advantage of a ruling by the Dispute Settlement Mechanism of the WTO to impose additional tariffs on EU imports. On October 18, 2019, the WTO authorized the US to adopt tariffs worth 7.5 billion dollars a year in compensation for the damages caused by the illegal aid granted by several European countries to Airbus, against the interests of Boeing and the laws of the free market.

The list of authorized tariffs included, in its Section 1, products directly related to the aerospace sector, where tariffs could amount to $15 \%$ and fall exclusively on the four European countries that produced Airbus components. Additionally, Section 2 included a large number of items subject to maximum tariffs of $25 \%$, applicable to a much larger list of EU countries. The products in this second section had little to do with Airbus activity, and included items ranging from wine, olive oil, cheese, or zinc. The list of products is provided in the annex.

Although the nature of these US protectionist actions is completely different than the other unilateral (probably illegal) tariffs analyzed because they are legal under WTO law, they severely affected a number of European exporters and eroded the confidence that European authorities had that the US could, at some point, reach a trade deal with the EU or collaborate to reform the WTO.

Finally, as the trade war between the US and China reach a temporary ceasefire in January 2020, Trump seemed determined to apply tariffs on European automobiles. Only the COVID-19 pandemic stopped him.

All in all, Trump's trade policy, summarized in his tweet "trade wars are good and 
easy to win," undermines the WTO, narrowly focuses on bilateral trade deficits, uses national security considerations to penalize allies (Bown \& Cimino-Isaacs, 2017) and negatively affects economic growth (Fajgelbaum et al., 2020).

With his actions, President Trump has weakened the confidence of his allies and continues to undermine the rules-based multilateral trading system. As Posen argues "U.S. President Donald Trump has rejected the idea that the world's economies all benefit when they play by the rules," "if the United States continues its retreat from economic leadership, it will impose serious pain on the rest of the world-and on itself." (2018, p. 28).

His actions make clear that the US has no interest in resolving trade issues through multilateral dialogue. A G-20 initiative already underway to deal with the global excess steel capacity caused by China has been derailed by these actions. And the constructive proposals to reform the WTO seem impossible as long as Trump remains in the White House. Moreover, the US response to the COVID-19 pandemic has also shown that the US President does not believe in international cooperation. It has blocked the G-20 response to the pandemic and it has also withdrawn from the World Health Organization.

The risks are huge. If US protectionism continues and other countries retaliate, the world could enter a protectionist spiral like that of the 1930s (Kindleberger, 1973). Only time will tell if Trump wins the November 2020 election or if he or his successor changes American trade policy. However, even with a democrat in the White House, it is likely that the economic and geopolitical confrontation between the US and China will continue. A democrat might have more interest than Trump in the transatlantic relation. In particular, instead of threatening European countries with higher tariffs if the EU does not increase agricultural imports from the US, a Biden Administration might resume the Transatlantic Trade and Investment Partnership (TTIP) launched during the Obama Administration in 2013 and suspended when Trump arrived to the White House. That, as we show below, will greatly benefit both the EU and Spain.

\section{Methodological background}

The discussion about optimal procedures for an ex ante evaluation of a new tariff's potential effects is broad and inconclusive, but there have been interesting reviews (Piermartini \& Teh, 2005; WTO-UNCTAD, 2012) aiming to orient the analyses of both researchers and policymakers. The WTO-UNCTAD (2012) describes the virtues and limitations of partial equilibrium (PE) and computable general equilibrium (CGE), noting a tradeoff in the choice between them. CGE has advantages in the accountability of inter-market linkages, which is usually applicable for long-term analysis at the aggregate level, whereas PE is usually more suitable for short-term and more disaggregated policy experiments. WTO-UNCTAD (2012) also reviews a list of powerful models, such as SMART, GSIM, TRIST and ATPSM. 
In this paper we have opted for the SMART simulation model, which enables us to estimate the main effects considered in the literature (Laird \& Yeats, 1986; Laird, 1997; Jammes \& Olarreaga, 2005; Piermartini \& Teh, 2005; Feenstra, 2015; and WTO-UNCTAD, 2012) and explains how a tariff on the imports of a given country can produce trade, revenue and consumer effects, both in the importing and the exporting country. The results depend to a large extent on the market structure, the product penetration in the importing country and the size of the country applying the tariff.

We have focused on the total trade effect computed by SMART, ${ }^{1}$ which accounts for the trade loss $^{2}$ and trade deviation effect (Laird \& Yeats, 1986).

The trade loss effect captures the trade reduction induced by an increase in tariffs and the resulting displacement of efficient producers that were delivering their lessexpensive products in the importing country (the US in our case). Such imports will be replaced by less-efficient domestic products. The standard case (small country) assumes full transmission of price changes when tariff distortions are introduced.

The trade diversion effect, on the other hand, is the substitution of goods from one set of foreign suppliers for goods from another set of foreign suppliers. It results from changes in relative import prices (including the tariff) of goods from the different sets of foreign suppliers and is due to changes in the differential between the rates. The trade diversion effect can expand or contract trade globally, and depends on the current level of imports from the US and the rest of the world, the percentage increase in tariffs on US imports with respect to tariffs remaining unchanged (exempted countries) and the elasticity of substitution (EoS) of the imports from the two sources. The greater the elasticity of substitution, the greater the trade diversion effects.

\subsection{SMART: a brief review}

We compute the effect of the new tariffs using the SMART simulation model developed by the WTO and the UNCTAD, included in the World Integrated Trade Solution (WITS). With this framework to facilitate the simulation, we use the most recent data on inter-national flows by country and product, as well as the updated TRAINS dataset for tariffs applicable to each delivery (2017). This tool enables us to determine the range of products subject to the tariff, computing the total trade effects in the exporting countries affected. This model has been used in several analyses (Khorana et al., 2009; Jallab et al., 2007; Gómez-Abella et al., 2013; Gaalya, 2015; Makochekanwa, 2014; Tian \& Yu, 2014; Kabir \& Salim, 2011; Munemo, 2013; and Pereira-Villa et al., 2012).

Following Laird and Yeats (1986) and related papers that apply SMART (Makochekanwa, 2014; Jammes \& Olarreaga, 2005; Khorana et al., 2009; Jallab

${ }^{1}$ SMART also delivers price, revenue and welfare effects from tariff variation in a given country or set of products. We focus on the trade effects of tariffs in the RoW, avoiding discussion of these effects.

${ }^{2}$ Usually the literature uses the concept of 'trade creation effect' to refer to a liberalization measure. To emphasize the likely negative effect of a new tariff, we instead use the concept of the 'trade loss effect'. 
et al., 2007), it is now convenient to briefly revise the main equations and variables used by SMART in our simulation about the total trade effect of the three new tariffs.

$T L_{i S R}$ - Trade loss effect on commodity $i$ imported from country $R$ into country $S$.

$T D_{i S R}-$ Trade diversion effect on commodity $i$ imported from $R$ into country $S$.

$M_{i S R}$ - Imports of commodity $i$ to country $S$ from exporting country $R$.

$M_{i S R W}-$ Imports of commodity $i$ by $S$ from the rest of the world.

$P_{i S R}$ - Price of commodity $i$ in country $S$ from country $R$.

$P_{i s R W}$ - Price of commodity $i$ in country $S$ from the rest of the world.

$t_{i S R}$ - Tariff ( $t_{1}$ and $t_{0}$ refer to post- and pre-integration tariffs).

$\eta$ - Import elasticity of demand in the importing country.

$\beta$ - Export supply elasticity (ESE).

$\lambda$ - Substitution elasticity (EoS).

The SMART simulation model measures Trade loss effect as follows:

$$
T L_{i S R}=M_{i S R}^{1} * \eta * \Delta t_{i S R} /\left(\left(1+t_{i S R}\right) *(1-(\eta / \beta))\right.
$$

Note that if the elasticity of export supply with respect to the world price is infinite then the denominator on the right-hand side of Equation [1] becomes unity and can be ignored.

We can rewrite the equation above as:

$$
T L_{i S R}=\eta * M_{i S R}^{1} \frac{\left(1+t_{i S R}^{1}\right)-\left(1+t_{i S R}^{0}\right)}{\left(1+t_{i S R}^{0}\right)}
$$

As noted in Laird and Yeats (1986), with extensive expansion, substitution and rearrangements, it is possible to obtain the following equation to calculate the Trade diversion effect:

$$
T D_{i S R}=\frac{M_{i S R}}{\sum M_{i S R}} \frac{M_{i S R} * \sum M_{i S R W} \frac{\Delta\left(P_{i S R} / P_{i s R W}\right)}{P_{i S R} / P_{i S R W}} \lambda}{\sum M_{i S R}+\sum M_{i S R W}+\sum M_{i S R} \frac{\Delta\left(P_{i S R} / P_{i S R W}\right)}{P_{i S R} / P_{i S R W}} \lambda}
$$

Equation [2] describes the terms of relative price movements, capturing movement due to changes in tariffs on the imports of countries affected by the new tariffs.

Finally, with Equation [3], we can compute the Product trade effect (PTE) as defined in this paper, just by adding TL and TD effects.

$$
P T E_{i S R}=T L_{i S R}+T D_{i S R}
$$

By default, SMART considers the same 'import demand elasticity' values for all the countries affected by the new tariff, but they may vary by product. Given that the product-mix within each of the sectors in our case study (i.e. the metal sector; the automotive sector and the aerospace, agricultural and industrial sectors) is different 
across countries, our simulation will have different import demand elasticities by country at that level of aggregation. Regarding the 'elasticity of substitution' (EoS), we assume the value set by default in SMART (1.5). For 'export supply elasticity' (ESE), we consider 75 a reasonable value for a big country in sectors with high concentration. Note that SMART assumes 99 for infinite elasticity by default for all products and partners, as it defaults to the case of a small country (see Equation [1.1]). Recently, Llano et al., 2020 analyzed the potential impact of a new tariff to the automotive sector, offering a sensitivity analysis with SMART using alternative elasticities. The results obtained in that article suggest that the values of 75 for the ESE and 1.5 for the EoS is reasonable for our analysis.

\subsection{Trade policy scenarios}

Our empirical analysis considers the following three cases with actual or potential effect on the EU28 and the Spanish economies:

Case 1: the imposition of a $25 \%$ tariff to all products included in the rubric HS72 "Iron and Steel" and a $10 \%$ tariff to the HS76 "Aluminum." All countries are considered as potential economies affected by the tariff except Argentina, Australia, Brazil, Canada, Mexico and South Korea.

Case 2: the imposition of a $25 \%$ tariff to products included in the rubrics HS-40, HS-84 and HS-87 referring to motor vehicles and parts. Applied only to the EU and to Japan.

Case 3: the imposition of a $15 \%$ tariff to products included in the rubric HS88 "Large Civil Aircraft", applied only to France, Germany, Spain and the United Kingdom. Additionally, a tariff of $25 \%$ is imposed on a long list of agricultural and industrial products. In this regard, the burden of these levies will fall on all EU countries. More detail about the products and countries affected by this complex case are reported in an Annex.

In this paper, we just focus on the effects on the EU28.

The three cases are relevant for the EU because they all destroy jobs, have adverse effects on exports and economic growth and, crucially, they undermine confidence between the two largest world economies, which have been closed geoeconomic allies for more than a century. In particular, all this protectionist measures might trigger a transatlantic trade war with dangerous implications for international stability and cooperation.

It is also important to mention, however, that the three measures are different in their justification and legality. Whereas the tariffs established as a retaliation for the Airbus subsidies are legal under WTO law, the other two are based on dubious national security considerations that are WTO-inconsistent.

Finally, and despite their legal and economic differences, it might be argued that the three measures are part of a protectionist package designed by the Trump Administration to rebalance the bilateral trade relation in favor of the US. The 
strategy is based on threat and undermines multilateralism in general and the WTOsystem in particular, which are highly valued by the EU and Spain.

\section{Descriptive Analysis}

We start by characterizing the most recent trade relationships between the US and the EU28 for the three cases described before.

TABLE 1

RANKING OF THE EXPORTERS OF METALS (HS 72\&76: IRON \& STEEL AND ALUMINUM) TO THE US

(Thousands of Euros)

\begin{tabular}{|c|c|c|c|}
\hline Rank & Exporters & $\begin{array}{l}\text { Export Change } \\
\text { in } 1000 €\end{array}$ & $\begin{array}{c}\text { Export Change/World } \\
\text { Export change }(\%)\end{array}$ \\
\hline 1 & Germany & $-623,302$ & 8.71 \\
\hline 2 & Netherlands & $-303,043$ & 4.24 \\
\hline 3 & Italy & $-254,287$ & 3.55 \\
\hline 4 & Sweden & $-252,111$ & 3.52 \\
\hline 5 & United Kingdom & $-241,011$ & 3.37 \\
\hline 6 & France & $-200,207$ & 2.80 \\
\hline 7 & Spain & $-149,610$ & 2.09 \\
\hline 8 & Austria & $-124,379$ & 1.74 \\
\hline 9 & Belgium & $-91,778$ & 1.28 \\
\hline 10 & Portugal & $-62,337$ & 0.87 \\
\hline 11 & Finland & $-48,467$ & 0.68 \\
\hline 12 & Luxembourg & $-34,104$ & 0.48 \\
\hline 13 & Slovenia & $-31,991$ & 0.45 \\
\hline 14 & Czech Republic & $-22,156$ & 0.31 \\
\hline 15 & Poland & $-19,555$ & 0.27 \\
\hline 16 & Slovak Republic & $-14,655$ & 0.20 \\
\hline 17 & Switzerland & $-12,798$ & 0.18 \\
\hline 18 & Romania & $-12,075$ & 0.17 \\
\hline 19 & Denmark & $-10,989$ & 0.15 \\
\hline 20 & Greece & $-6,839$ & 0.10 \\
\hline 21 & Ireland & $-2,667$ & 0.04 \\
\hline 22 & Croatia & $-1,917$ & 0.03 \\
\hline 23 & \begin{tabular}{|l|} 
Hungary \\
\end{tabular} & -586 & 0,01 \\
\hline 24 & Bulgaria & -555 & 0.01 \\
\hline 25 & Cyprus & -235 & 0,00 \\
\hline 26 & Estonia & -75 & 0.00 \\
\hline 27 & Latvia & -48 & 0.00 \\
\hline 28 & Malta & -12 & 0.00 \\
\hline
\end{tabular}

SOURCE: Own elaboration based on data from UN Comtrade. 
In Table 1 we show the ranking of EU28 countries in relation to their most recent figures of exports to the US of the metal's products affected by the first tariffs analyzed (HS 72\&76). The results show a strong concentration of the effects in Germany, followed by The Netherlands, Italy, Sweden, UK and France. Spain remains in the $7^{\text {th }}$ position, representing $2.09 \%$ of the total trade reduction of the impact over the whole World. To this regard, it is important to remember that the main aim of this tariffs was to reduce the US imports coming from non-EU countries such as China and Russia. Indeed, the EU28 almost managed to be exempted from the tariffs.

In Table 2 we show the US trade deficit with the world (last column) as well as with each of the four European countries sanctioned in the Airbus dispute. Rows include only the first 30 products on the list, ordered from highest to lowest in relation to their trade deficit between the US and the world. The data comes from Comtrade (UN), they are expressed in millions of dollars and refer to 2018. For clarity, in the last row of the table the total bilateral balance of the US is added with each of these markets. Likewise, together with each record by rows, the last row records the percentage that the bilateral balance of each product in the ranking represents over the total bilateral balance, expressed in absolute value. Thus, for example, in 2018 the US registered a trade deficit with the world of 946 billion dollars, of which $1.6 \%$ corresponds to the product "6110. Sweaters, pullovers...", included in the list of affected products. This item would hardly be of relative importance in the bilateral balances with the four European guilty countries, knowing that even in the exchanges with Germany and the UK, the bilateral balance of said product is positive for the US. The case of the following balance in the ranking is somewhat different: it would be the product "8803. Parts of new civil aircraft...", this item, directly linked to the aerospace sector, would account for $1.4 \%$ of the total US trade deficit with the world, which accounts for $34.2 \%$ of the US negative bilateral balance with the United Kingdom, $10.7 \%$ with France, $1.9 \%$ with Spain or $0.5 \%$ with Germany.

Remarkable is also the case of product "2208. Grape Brandy...", which accounts for up to $40.5 \%$ of the US-UK bilateral balance, while $15.1 \%$ with France or $2.1 \%$ with Spain.

The case of item "880240. New aircraft for civil use" is also significant, since it represents $21.2 \%$ of the US-France bilateral balance or $2.3 \%$ of the US-Germany. Another unique case for Spain would be that of the product "1509. Olive oil...", with a bilateral balance of -438.34 million euros, which represents $11 \%$ of the bilateral trade deficit observed between the US and Spain in 2018.

All these figures indicate that, even if the United States imposed a 100\% tariff on all these items, until imports of these products-origins were completely cut off, the overall effect on the US bilateral and absolute deficit would be limited, although not negligible.

Table 3, identifies the Ranking of the EU28 based on their exports to the US imports of motor vehicles for the last three years available (2016-2018). 
-

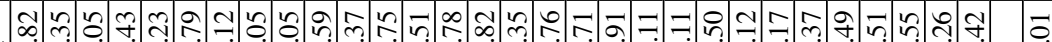

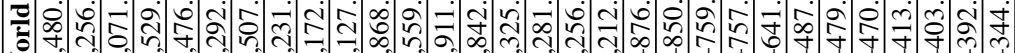
वै

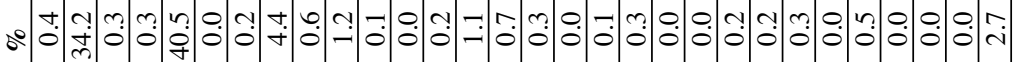

ก ก

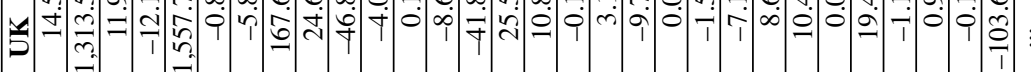

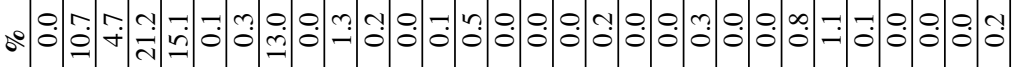

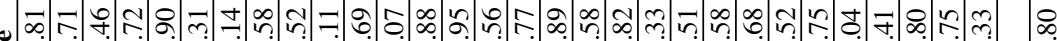

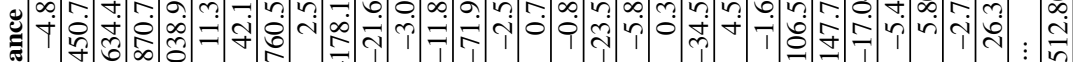

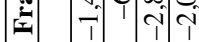

•

0.

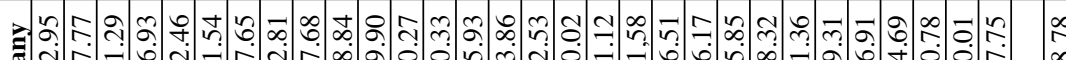

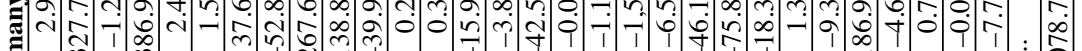
हี तै ב2

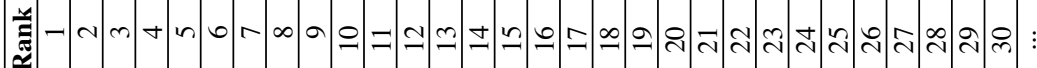


What immediately stands out is the share of cars in total US imports (HS-87); they represent $12.19 \%$. Also noteworthy is the strong concentration of flows in three sources: Germany (4.64\%), United Kingdom (1.73\%) and Italy $(0.97 \%)$.

Spain appears in $6^{\text {th }}$ position, with a narrow share of $0.26 \%$ of the sector's total world exports to the US.

We now turn our attention to the weight of exports from the automotive sector (HS87) in the total exports that each of these countries dispatches to the US (fourth column of Table 3). The most exposed country here is Slovakia, $68.55 \%$ of whose

\section{TABLE 3}

US IMPORTS OF MOTOR VEHICLES: THE 28 COUNTRIES OF THE EUROPEAN UNION. AGGREGATE FIGURES, 2016-2018

(Millions of $€$ )

\begin{tabular}{|c|l|r|r|r|r|}
\hline \multirow{2}{*}{ Rank } & \multicolumn{1}{|c|}{ Target country } & EU & $\begin{array}{c}\text { EU country/ } \\
\text { EU total } \\
(\boldsymbol{\%})\end{array}$ & World & $\begin{array}{c}\text { EU/World } \\
(\mathbf{\%})\end{array}$ \\
\cline { 3 - 6 } & & $(1)$ & $(2)=1 /$ Total $(1)$ & $(3)$ & $(4)=1 / 3$ \\
\hline & Total USA (rest of the world) & $\mathbf{1 , 4 9 9 , 2 6 2}$ & $\mathbf{1 0 0}$ & $\mathbf{1 2 , 2 9 9 , 3 5 1}$ & $\mathbf{1 , 2 1 9}$ \\
\hline 1 & Germany & 69,559 & 4.64 & 308,508 & 22.55 \\
\hline 2 & United Kingdom & 25,913 & 1.73 & 144,570 & 17.92 \\
\hline 3 & Italy & 14,585 & 0.97 & 130,454 & 11.18 \\
\hline 4 & Sweden & 6,676 & 0.45 & 28,531 & 23.40 \\
\hline 5 & Slovakia & 5,716 & 0.38 & 8,339 & 68.55 \\
\hline 6 & Spain & 3,918 & 0.26 & 40,659 & 9.64 \\
\hline 7 & Hungary & 3,424 & 0.23 & 13,376 & 25.60 \\
\hline 8 & Austria & 2,927 & 0.20 & 31,143 & 9.40 \\
\hline 9 & Finland & 2,610 & 0.17 & 15,373 & 16.98 \\
\hline 10 & Belgium & 2,267 & 0.15 & 42,963 & 5.28 \\
\hline 11 & France and Monaco & 1,892 & 0.13 & 128,191 & 1.48 \\
\hline 12 & Netherlands & 1,503 & 0.10 & 51,186 & 2.94 \\
\hline 13 & Poland & 975 & 0.07 & 18,434 & 5.29 \\
\hline 14 & Czech Republic & 716 & 0.05 & 12,230 & 5.85 \\
\hline 15 & Romania & 334 & 0.02 & 5,916 & 5.64 \\
\hline 16 & Denmark & 171 & 0.01 & 21,139 & 0.81 \\
\hline 17 & Portugal & 135 & 0.01 & 9,324 & 1.45 \\
\hline 18 & Greece & 117 & 0.01 & 3,718 & 3.15 \\
\hline 19 & Slovenia & 70 & 0.00 & 2,062 & 3.37 \\
\hline 20 & Ireland & 22 & 0.00 & 128,970 & 0.02 \\
\hline 21 & Luxembourg & 21 & 0.00 & 1,361 & 1.53 \\
\hline 22 & Bulgaria & 17 & 0.00 & 1,974 & 0.85 \\
\hline 23 & Latvia & 7 & 0.00 & 1,323 & 0.57 \\
\hline 24 & Estonia & 7 & 0.00 & 2,220 & 0.33 \\
\hline 25 & Croatia & 5 & 0.00 & 1,231 & 0.41 \\
\hline 26 & Lithuania & 0.00 & 3,523 & 0.09 \\
\hline 27 & Malta & 0 & 0.00 & 1,409 & 0.05 \\
\hline 28 & Cyprus & 3 & & & 0.03 \\
\hline
\end{tabular}

SOURCE: Own elaboration based on data from UN Comtrade. 
exports to the US are concentrated in this sector. It is followed by Hungary (25.6\%) and Sweden $(23.40 \%)$. The share of automotive exports in Spain's total exports to the US is relatively low $(9.64 \%)$ - lower than it is in Germany $(22.55 \%)$, the UK $(18 \%)$ or Italy $(11.18 \%)$.

\section{Results}

With the previous figures in mind, we now turn to review the most salient results obtained in our simulations using SMART, with a focus on the trade effects over the EU28.

\subsection{Results: A general overview}

To start, Figure 1 shows the total effects obtained using our preferred scenarios $(\mathrm{EoS}=1.5 ; \mathrm{ESE}=75)$ for the three cases considered, with the countries ranked in decreasing order.

As expected, the largest effects in terms of export reductions concentrate in the countries that faced a higher exposure to the US market in the three sectors considered, namely, Germany, UK, Italy and France. Spain appears in the sixth position. Therefore, the impact is moderate if it is compared to its relative size within the EU, and especially if one takes into account that Spain is the second EU largest car producer.

FIGURE 1

RANKING OF THE TOTAL TRADE EFFECT BY THE EU28 COUNTRIES (In thousands of $€$ ) (Smart simulation using: $\mathrm{ESE}=75 \% ; \mathrm{EoS}=1.5$ )

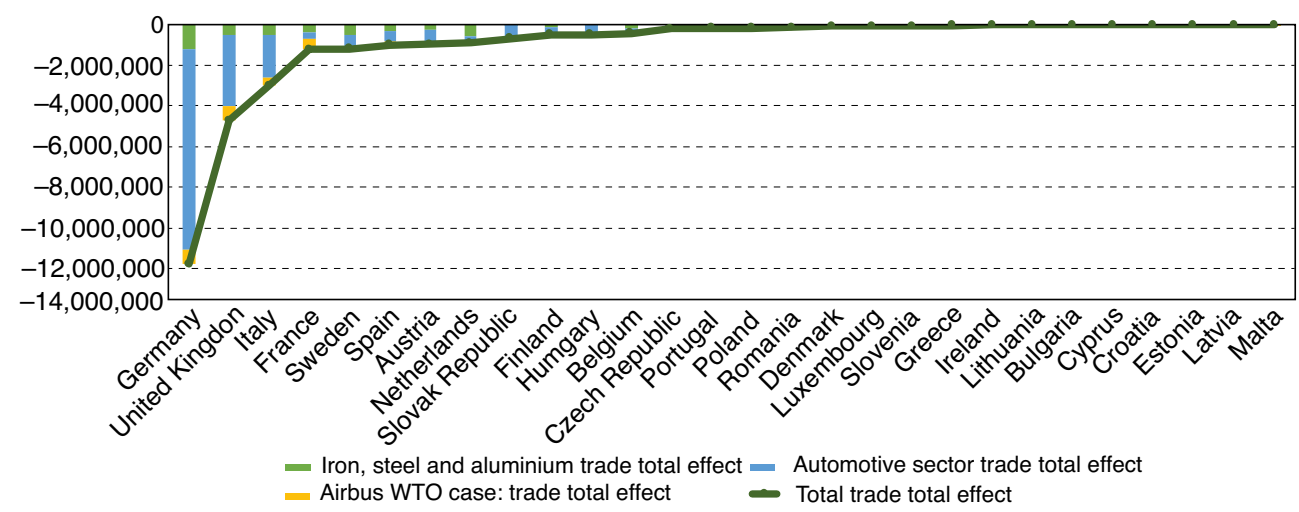

SOURCE: Own elaboration. 
In addition to the relative position of each country, it is also relevant to consider the share of each of the three cases within each total effect, which suggests that the largest impacts might be generated by the tariffs to the automotive sector, followed by the metals and the measures adopted in relation to the Airbus WTO dispute. Thus, the two measures already at play have the lowest impacts, while the potential new measure (those on cars) might have the largest.

Complementary, Figure 2 shows in three alternative maps the trade effects obtained for the baseline scenario $(E S E=75 ; E o S=1.5)$, measure in relative terms to the country GDP in 2018 (all measure in current \$). The maps use 10 different colors, where the categories are defined using natural brakes, as the best way to identify the

FIGURE 2

\section{TOTAL EXPORT CHANGE OF THE THREE CASES (In \% of country GDP 2018)}
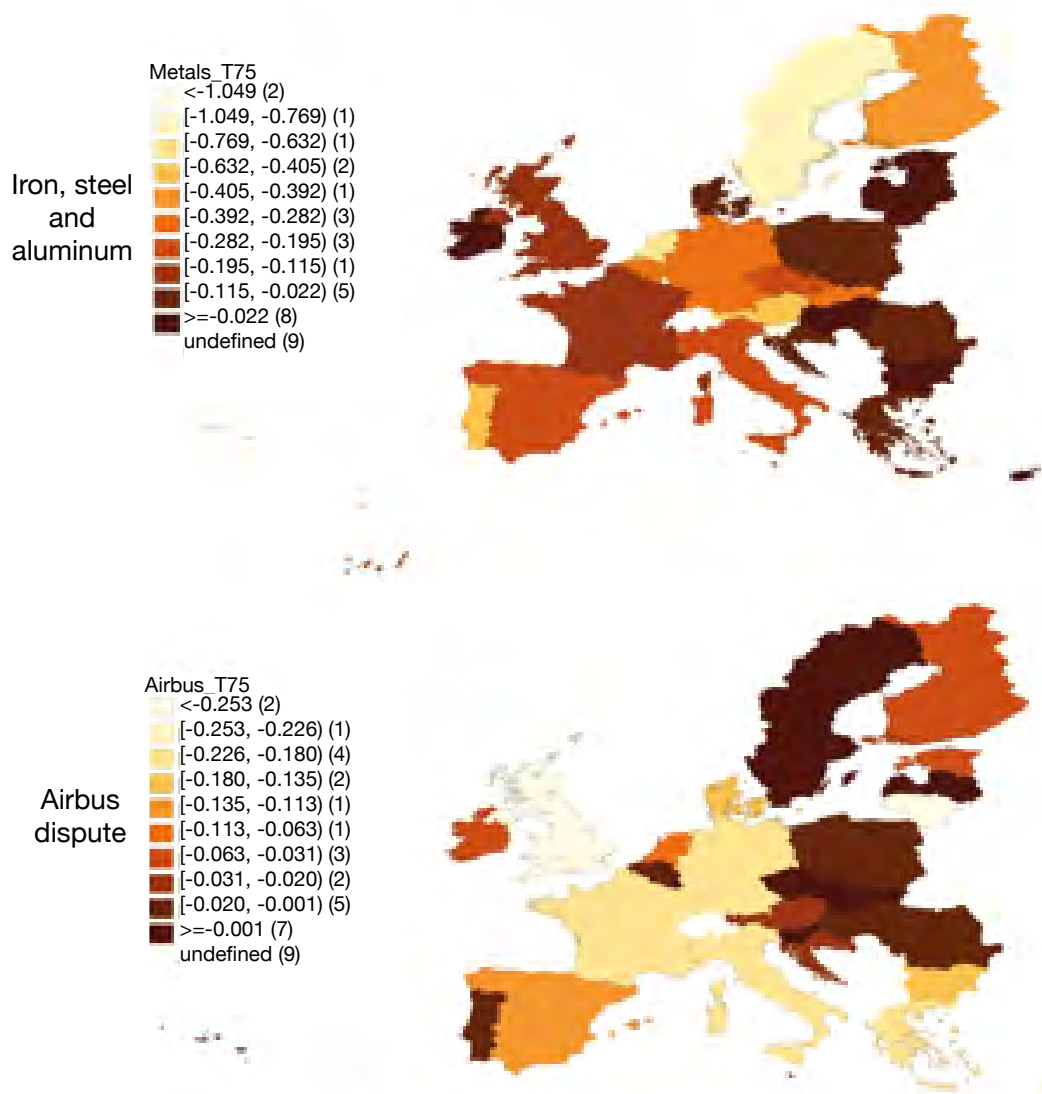

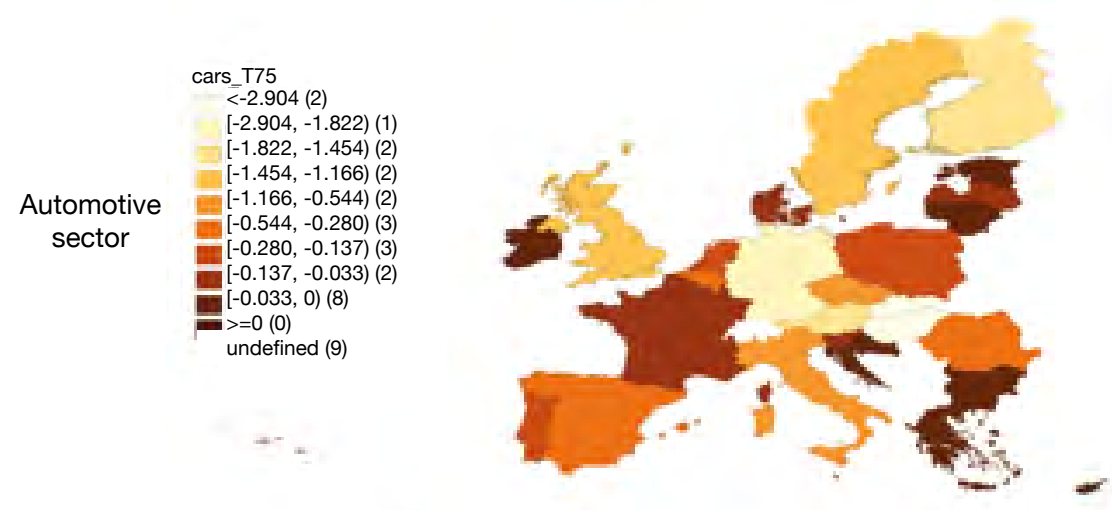

NOTE: since the effects are mainly negative, the lighter the color the higher the impact. SOURCE: Own elaboration.

heterogeneity of impacts by countries. To better interpret the Maps, is important to consider that, since the effects are mainly negative, the lighter the color the higher the impact.

In this case, the largest overall impact corresponds to Slovakia $(-0.8 \%$ of its 2018 GDP), followed by Hungary $(-0.4 \%)$, Germany $(-0.3 \%)$, Sweden $(-0.3 \%)$, UK $(-0.2 \%)$, Austria $(-0.2 \%)$ or Finland $(-0.2 \%)$, while the impact on the Spanish economy remains in a moderate $-0.1 \%$.

Thus, the relative importance of the impact in percentage of the GDPs offers a different view to the absolute value impact, something that can be explained by the largest GDPs of the main countries affected, as well as the high specialization in some of the products targeted in certain countries (i.e. car industry in Slovakia and Hungary). Even with that, the impact in relative terms to the German's GDP is substantial, while the one for Spain remains in an upper-middle range, below its economic size in the EU.

Finally, Table 4 shows the ranking of the main "country-product" dyads according to their total export decrease as predicted in our simulation using SMART and the preferred scenarios. Consistently with the previous results, the eight first main impacts concentrate in products related in the automotive sector, with a prevalence in Germany, and less intensely, in the UK, Italy or France. Note that for each flow, the total trade effect is decomposed in the two components provided by the SMART simulation, that is, the trade loss effect and the deviation effect. To this regard, in most cases, the negative effect is due to the trade loss effect, which accounts for about $60 \%$ of the total in the main flows. 
TABLE 4

RANKING OF THE MAIN 'COUNTRY-PRODUCT’ AFFECTED BY THE TARIFFS IN TERMS OF TOTAL TRADE EFFECT, AND ITS TWO COMPONENTS: DESTRUCTION VS. DIVERSION

(SMART simulation using: $\mathrm{ESE}=75$; $\mathrm{EOS}=1.5$ )

\begin{tabular}{|c|c|c|c|c|c|c|c|}
\hline \multirow{2}{*}{ Rank } & \multirow{2}{*}{ Country } & \multirow{2}{*}{$\begin{array}{l}\text { Product } \\
\text { HS code }\end{array}$} & \multirow{2}{*}{\begin{tabular}{|c|} 
Trade total effect \\
1,000 euros \\
\end{tabular}} & \multicolumn{2}{|c|}{ Trade_Destruction } & \multicolumn{2}{|c|}{ Trade_Diversion } \\
\hline & & & & 1,000 euros & $\%$ & 1,000 euros & $\%$ \\
\hline 1 & Germany & 870323 & $-4,677,728$ & $-2,826,743$ & 60 & $-1,789,436$ & 38 \\
\hline 2 & Germany & 870324 & $-1,502,234$ & $-883,252$ & 59 & $-599,215$ & 40 \\
\hline 3 & U.K. & 870323 & $-1,153,904$ & $-705,980$ & 61 & $-432,741$ & 38 \\
\hline 4 & Italy & 870323 & $-1,117,024$ & $-683,493$ & 61 & $-418,833$ & 37 \\
\hline 5 & U. K. & 870324 & $-1,068,775$ & $-630,750$ & 59 & $-423,963$ & 40 \\
\hline 6 & France & 880240 & $-586,767$ & $-343,507$ & 59 & $-235,540$ & 40 \\
\hline 7 & Germany & 840734 & $-571,627$ & $-283,167$ & 50 & $-280,938$ & 49 \\
\hline 8 & Sweden & 870323 & $-564,468$ & $-345,963$ & 61 & $-211,078$ & 37 \\
\hline 9 & Germany & 72 & $-532,582$ & $-441,230$ & 83 & $-86,005$ & 16 \\
\hline 10 & Germany & 870840 & $-529,102$ & $-329,951$ & 62 & $-192,189$ & 36 \\
\hline 11 & U.K. & 220830 & $-527,369$ & $-367,328$ & 70 & $-153,102$ & 29 \\
\hline 12 & Germany & 840820 & $-480,421$ & $-480,421$ & 100 & 0 & 0 \\
\hline 13 & U. K. & 870322 & $-469,619$ & $-175,621$ & 37 & $-287,819$ & 61 \\
\hline 14 & Italy & 870324 & $-430,046$ & $-255,089$ & 59 & $-169,298$ & 39 \\
\hline 15 & Slovakia & 870323 & $-397,551$ & $-243,778$ & 61 & $-148,542$ & 37 \\
\hline 16 & Germany & 880240 & $-371,397$ & $-220,894$ & 59 & $-145,616$ & 39 \\
\hline 17 & Hungary & 870323 & $-366,392$ & $-224,691$ & 61 & $-136,879$ & 37 \\
\hline 18 & Austria & 840820 & $-362,660$ & $-362,660$ & 100 & 0 & 0 \\
\hline 19 & Finland & 870323 & $-349,177$ & $-214,145$ & 61 & $-130,437$ & 37 \\
\hline 20 & U. K. & 870333 & $-341,131$ & $-341,131$ & 100 & 0 & 0 \\
\hline 21 & Germany & 870829 & $-331,772$ & $-166,049$ & 50 & $-161,358$ & 49 \\
\hline 22 & Netherlands & 72 & $-287,532$ & $-224,404$ & 78 & $-60,644$ & 21 \\
\hline 23 & Sweden & 72 & $-244,358$ & $-208,332$ & 85 & $-33,537$ & 14 \\
\hline 24 & Spain & 870323 & $-241,483$ & $-148,144$ & 61 & $-90,162$ & 37 \\
\hline 25 & Slovakia & 870324 & $-220,837$ & $-131,198$ & 59 & $-86,733$ & 39 \\
\hline 26 & Germany & 870899 & $-220,499$ & $-71,536$ & 32 & $-146,062$ & 66 \\
\hline 27 & U.K. & 72 & $-217,502$ & $-163,023$ & 75 & $-52,205$ & 24 \\
\hline 28 & Italy & 72 & $-207,282$ & $-179,482$ & 87 & $-25,713$ & 12 \\
\hline 29 & Belgium & 870323 & $-174,306$ & $-106,953$ & 61 & $-65,059$ & 37 \\
\hline 30 & France & 72 & $-172,110$ & $-151,212$ & 88 & $-19,310$ & 11 \\
\hline 31 & Germany & 870894 & $-168,393$ & $-83,051$ & 49 & $-83,126$ & 49 \\
\hline 32 & Germany & 840991 & $-164,742$ & $-114,319$ & 69 & $-48,255$ & 29 \\
\hline 33 & Germany & 840999 & $-160,566$ & $-75,392$ & 47 & $-83,061$ & 52 \\
\hline 34 & Italy & 840820 & $-153,897$ & $-153,897$ & 100 & 0 & 0 \\
\hline 35 & U. K. & 840734 & $-149,586$ & $-76,379$ & 51 & $-71,239$ & 48 \\
\hline 36 & Germany & 870850 & $-137,460$ & $-57,273$ & 42 & $-78,378$ & 57 \\
\hline 37 & Austria & 840734 & $-134,233$ & $-68,603$ & 51 & $-63,864$ & 48 \\
\hline 38 & Germany & 870830 & $-132,021$ & $-64,056$ & 49 & $-66,228$ & 50 \\
\hline 39 & Spain & 72 & $-127,475$ & $-108,770$ & 85 & $-17,860$ & 14 \\
\hline 40 & \begin{tabular}{|l|} 
Netherlands \\
\end{tabular} & 870323 & $-127,203$ & $-78,061$ & 61 & $-47,468$ & 37 \\
\hline 41 & Austria & 870324 & $-114,300$ & $-67,958$ & 59 & $-44,838$ & 39 \\
\hline 42 & Germany & 401110 & $-112,455$ & $-36,009$ & 32 & $-74,967$ & 67 \\
\hline 43 & U. K. & 870332 & $-111,034$ & $-111,034$ & 100 & 0 & 0 \\
\hline 44 & Netherlands & 721012 & $-106,105$ & $-79,782$ & 75 & $-24,927$ & 23 \\
\hline 45 & Austria & 72 & $-102,326$ & $-85,075$ & 83 & $-16,240$ & 16 \\
\hline 46 & Spain & 840991 & $-100,461$ & $-69,847$ & 70 & $-29,292$ & 29 \\
\hline 47 & Germany & 76 & $-83,662$ & $-74,611$ & 89 & $-8,395$ & 10 \\
\hline 48 & Belgium & 72 & $-82,501$ & $-69,177$ & 84 & $-12,645$ & 15 \\
\hline 49 & Germany & 870880 & $-79,248$ & $-19,459$ & 25 & $-58,746$ & 74 \\
\hline 50 & Germany & 721012 & $-79,184$ & $-59,946$ & 76 & $-18,195$ & 23 \\
\hline
\end{tabular}

SOURCE: Own elaboration. 


\subsection{Further discussion: impacts on sustainability}

Now it is time to connect the previous analysis with the leitmotiv of this special issue, as well as with the dramatic crisis we are all experiencing due to the COVID-19 pandemic.

There is a tradeoff between globalization and sustainability (Cherniwchan, et al, 2017; Copeland, et al., 2004). International trade and the fragmentation of the production chain imply that the intermediate products (part and components) embodied in each good and service travel larger distances and generates heavier GHG emissions. As mentioned in the introduction, protectionism measures and trade conflicts push against globalization, promoting the insourcing of (part) of the fragmented stages of production in favor of the domestic economy.

For example, Cristea et al. (2013) studied the GHG emissions associated with international trade using origin-destination flows by mode for the whole world. These authors collect extensive data on worldwide trade by transport mode and use it to provide detailed comparisons of GHG emissions associated with output versus international transport of traded goods. According to their analysis, international transport is responsible for 33\% of worldwide trade-related emissions and over $75 \%$ of emissions for major manufacturing categories. Their approach covers emissions associated with both the production (output) and the transport of goods to destinations abroad and allows them to distinguish between the two. Moreover, for the latter they also consider the scale effect (i.e. changes in emissions due to changes in demand for international transport) and the composition effect (i.e. changes in the transport mode mix). They conclude that including transport dramatically changes the ranking of countries by emissions per dollar of trade. They go on to investigate whether trade inclusive of transport can lower emissions. In one quarter of cases, the difference in output emissions is more than enough to compensate for the emissions cost of transport. The main limitation of their approach is to consider international trade in isolation from internal freight flows, which in most countries account for a larger share of economic activity.

Complementary, Yang et al. (2019), analyzed the environmental implications of the inter-national and inter-regional trade in China, considering the production and consumption side of the issue, measuring the potential impact on the emissions in a hypothetical scenario of no-trade, a very relevant scenario within the COVID-19 pandemic.

To this regard, it is expected that the current COVID-19 shock will push economies towards security against efficiency and to shorten value chains. This natural inbound movement is expected to produce similar results than a wave of protectionism, in this case, based on real national security reasons. This will probably lead to lower GHG emissions. 


\section{Conclusions}

The aim of this article has been to estimate the impact of recent American tariffs on European economies. The results are relevant in several dimensions. The impacts obtained show that trade effects can create important reductions in output and employment in the EU, with a special impact on Germany, the UK, Italy and France. The impact over the Spanish economy will be important, ranking $6^{\text {th }}$ in the context of the entire EU28.

According to our results, the largest impacts might be generated by the tariffs to the automotive sector (which had not been yet imposed as this paper went to press), followed by the metals and the tariffs related to the Boeing-Airbus dispute. Thus, the two measures already at play have the lowest impacts, but the worst shock, by far, is still pending on Trump's final decision about cars.

As commented before, the analysis conducted here is limited, and opens several lines of future research. On the one hand, we assume the limitations corresponding to a partial equilibrium approach, able to tackle just with the trade loss/deviation effects. To this regard, we expect to complement our current analysis incorporating a input-output analysis, computed at the international and interregional level, which includes the additional spillover effects caused by the intermediate demand between countries (WIOD tables) and regions within Spain (SIRIO tables). A first article has been published for the case of the metals (Llano et al, 2019), while other two are in preparation, for the other two cases. Furthermore, it will be interesting to incorporate additional macro-economic effects such as the ones linked to the rise in uncertainty and its heterogenous effects by sectors and countries, something that has been recently addressed by several relevant reports (European Central Bank, 2018; 2019).

Unfortunately, the COVID-19 current crisis and the way in which the EU and its member states are managing it, might introduce new barriers to the free movement of goods, services, people and capital. As commented before, this could trigger a general reaction of families, firms and nations towards retracting in favor of regionalization and the domestic economies, giving the last push to the hyper-globalization process observed in the previous decades.

In sum, in this paper we try to link the trade war, which drove the main discussion of the IMF and European Central Bank (ECB) global outlooks in the last autumn, with the lemma of this current special issue, and with the current COVID-19 crisis, that will define how our lives proceed in the coming years. 


\section{References}

Baldwin, R. (2020). COVID, hysteresis, and the future of work. Vox.eu, May 29th. https:// voxeu.org/article/COVID-hysteresis-and-future-work

Borrell, J. (2020). El mundo del mañana ya está aquí. Real Instituto Elcano. http:// www.realinstitutoelcano.org/wps/portal/rielcano_es/contenido?WCM_GLOBAL_ CONTEXT=/elcano/elcano_es/zonas_es/borrell-el-mundo-del-manana-ya-esta-aqui

Bown, C., \& Cimino-Isaacs, C. (2017). Will Trump Invoke National Security to Start a Trade War? Trade and Investment Policy Watch, July 5. Peterson Institute for International Economics. https://www.piie.com/blogs/trade-investment-policy-watch/ will-trump-invoke-national-security-start-trade-war

Cherniwchan, J., Copeland, B. R., Taylor, M. S. (2017). Trade and the environment: New methods, measurements, and results. Annual Review of Economics, 9, 59-85.

Copeland, B. R., \& Taylor, M. S. (2004). Trade, growth, and the environment. Journal of Economic Literature, 42(1), 7-71.

Cristea, A., Hummels, D., Puzzello, L., \& Avetisya, M. (2013). Trade and the greenhouse gas emissions from international freight transport. Journal of Environmental Economics and Management, 65(1), 153-173.

European Central Bank (2019). The economic implications of rising protectionism: a euro area and global perspective. ECB Economic Bulletin, 3.

European Central Bank (2018). Macroeconomic implications of increasing protectionism. ECB, Economic Bulletin 6.

Fajgelbaum, P. D., Goldberg, P. K., Kennedy, P. J., Khandelwal, A. K. (2020). The Return to Protectionism. The Quarterly Journal of Economics, 135(1), 1-55. https://doi.org/10.1093/qje/qjz036

Feenstra, R.C. (2015). Advanced International Trade: Theory and Evidence. Princeton University Press; Second Edition.

Gaalya, M.S. (2015). Uganda's Trade and Revenue Effects with the EAC Countries, DRC and Sudan. Modern Economy, 6, 338-357.

Gómez-Abella, D., Pereira-Villa, C. M., \& Gaitán-Guerrero, L. A. (2013). Impacto de un TLC en el comercio entre Colombia y Turquía. Cuadernos de Administración, 26(46), 159-199.

Jallab, M. S., Abdelmalki, L., \& Sandretto, R. (2007). The Free Trade Agreement Between the United States and Morocco: The Importance of a Gradual and Assymetric Agreement. Journal of Economic Integration, 22(4), 852-887.

Jammes, O., \& Olarreaga, M. (2005). Explaining SMART and GSIM. The World Bank. http://wits.worldbank.org/witsweb/download/docs/explaining_smart_and_gsim.pdf

Kabir M., \& Salim, R. (2011). Analysing Potential Effects of Preferential Liberalisation in Some Asian Emerging Economies. International Economic Journal, 25(2), 191-213.

Kindleberger, C. P. (1973). History of the World Economy in the Twentieth Century: The World in Depression 1929-1939. Allen Lane the Penguin Press.

Khorana, S. Kimbugwe, K., \& Perdikis, N. (2009).Assessing the Welfare Effects of the East African Community Customs Union's Transition Arrangements on Uganda. Journal of Economic Integration 24(4), 685-708.

Laird, S., \& Yeats, A. (1986).The UNCTAD Trade Policy Simulation Model: A Note on the Methodology, Data and Uses (Discussion Paper No. 19). UNCTAD. 
Laird, S. (1997). Quantifying commercial policies. In Francois, J. and Reinert, K. (Eds.), Applied Methods for Trade Policy Analysis: A Handbook. Cambridge University Press.

Lovely, M.E., Cohen-Setton, J., \& Jung, E. (2018). Vehicular Assault: Proposed Auto Tariffs Will Hit American Car Buyers' Wallets. Policy Brief 18-16. Peterson Institute for International Economics. https://www.piie.com/system/files/documents/pb18-16.pdf

Llano, C., Pérez, J., Steinberg, F., \& Hewings, G. J. D. (2019). Global and regional effects of the US tariffs on iron, steel and aluminium: A SMART combination of models with a focus on Spain. Regional Science Policy Practice, 11(3), 525-547. https://doi.org/10.1111/ rsp3.12198

Llano, C., Pérez, J., El Khatabi, F., \& Steinberg, F. (2020). Weaponized trade policy: the impact of US tariffs on the European automobile sector. Economic Systems Research. https://doi.org/10.1080/09535314.2020.1804330

McKinsey Global Institute (2019). Globalization in transition: the future of trade and value chains. https:/www.mckinsey.com/ /media/McKinsey/Featured\%20Insights/ Innovation/Globalization $\% 20 \mathrm{in} \% 20$ transition $\% 20 \mathrm{The} \% 20$ future $\% 20 \mathrm{of} \% 20$ trade $\% 20$ and $\% 20$ value $\% 20$ chains/MGI-Globalization $\% 20 \mathrm{in} \% 20$ transition-The-future-of-tradeand-value-chains-Full-report.ashx

Makochekanwa, A. (2014). Welfare Implications of COMESA-EAC-SADC Tripartite Free Trade Area. African Development Review, 26(1), 186-202.

Munemo, J. (2013). Trade between China and South Africa: Prospects of a Successful SACUChina Free Trade Agreement. African Development Review, 25(3), 303-329.

Ortega, A. (2020). The Deglobalization Virus. Elcano Blog, 17.03.2020. https://blog. realinstitutoelcano.org/en/the-deglobalisation-virus/

Otero-Iglesias, M., \& Steinberg, F. (2017). La economía mundial ante 2017. Real Instituto Elcano. http://www.realinstitutoelcano.org/wps/portal/rielcano_es/contenido?WCM_ GLOBAL_CONTEXT=/elcano/elcano_es/zonas_es/economia+internacional/ari5-2017steinberg-oteroiglesias-economia-mundial-ante-2017

Pereira-Villa, C. M., Gómez-Abella, D., \& Omar-Herrera, L. (2012). The Colombia-Canada Free Trade Area: A Partial Equilibrium Simulation. Semestre Económico, 15(31), 15-42.

Piermartini, R., \& Teh, R. (2005). Demystifying modelling methods for trade policy (No 10). WTO Discussion Paper. http://hdl.handle.net/10419/107045

Posen, A. S. (2018). The post-American world economy: Globalization in the Trump era. Foreign Affairs, 97(2), 28-38.

Rodrik, D. (2018a). From globalization to Hyper-Globalization and Back. Rhodes Center Podcast.https://drodrik.scholar.harvard.edu/links/globalization-hyper-globalization-andback

Rodrik, D. (2018b). Populism and the economics of globalization. Journal of International Business Policy, 1(1-2), 12-33.https://drodrik.scholar.harvard.edu/publications/populismand-economics-globalization

Steinberg, F. (2020). El futuro de la globalización. Real Instituto Elcano. http://www. realinstitutoelcano.org/wps/portal/rielcano_es/contenido?WCM_GLOBAL_ CONTEXT=/elcano/elcano_es/zonas_es/comentario-steinberg-el-futuro-de-laglobalizacion

Tian W., \& Yu M. (2014). Measuring the Impact of Trade Protection on Industrial Production Size. Review of Development Economics, 18(2), 231-253. https://doi.org/10.1111/rode.12081 
United Nations (2020). COVID-19: Implications for Trade and Environment. https://wedocs.unep.org/bitstream/handle/20.500.11822/32205/Covid.pdf

Ward, J. (2020). Pandemic Is Last Nail in Globalization's Coffin, Says Carmen Reinhart. Bloomberg. https://www.bloomberg.com/news/articles/2020-05-21/reinhart-sayspandemic-is-last-nail-in-globalization-s-coffin

WITS (2019). World Integrated Trade Solutions. https://wits.worldbank.org/WITS/WITS/ Restricted/Login.aspx

WTO-UNCTAD, (2012). A Practical Guide to Trade Policy Analysis. https://www.wto.org/ english/res_e/publications_e/practical_guide12_e.htm

World Trade Organization. (2020). Trade set to plunge as COVID-19 pandemic upends global economy. https://www.wto.org/english/news_e/pres20_e/pr855_e.htm

Yang X., Feng, K., Su, B., Zhang, W., \& Huang, S. (2019). Environmental efficiency and equality embodied in China's inter-regional trade. Science of The Total Environment, 672, 150-161. https://doi.org/10.1016/j.scitotenv.2019.03.450. 


\section{ANNEX}

\section{PRODUCTS INCLUDED IN THE LIST OF PRODUCTS AFFECTED BY THE BOEING-AIRBUS TRADE DISPUTE WITHIN THE WTO}

Based on the WTO verdict, the US Ministry of Commerce has published the list of products on which the new tariffs will fall from October 18. The list considers two sections. In this Annex we give more information about the product-country list considered in that protectionism measure, and how they have been introduced in our simulation.

The products that are enumerated and described in Section 1 of this Annex are being considered for additional import duties if they are the product of any of the following four member States of the European Union: France, Germany, Spain or the United Kingdom.

\begin{tabular}{|c|c|c|c|c|c|}
\hline $\begin{array}{c}\text { Section } \\
\mathbf{1}\end{array}$ & $\begin{array}{c}\text { Tariff } \\
(\boldsymbol{\%})\end{array}$ & Affected countries & Affected products & EoS & ESE \\
\hline Part 1 & 15 & $\begin{array}{c}\text { France, Germany, Spain and the } \\
\text { United Kingdom }\end{array}$ & 880240 & 1.5 & 75 \\
\hline
\end{tabular}

The products that are enumerated and described in Section 2 of this Annex are being considered for additional import duties if they are the product of any of the twenty-eight member States of the European Union.

\begin{tabular}{|c|c|c|c|c|c|}
\hline $\begin{array}{l}\text { Section } \\
2\end{array}$ & $\underset{(\%)}{\operatorname{Tariff}}$ & Affected countries & Affected products & EoS & ESE \\
\hline Part 2 & 25 & EU28 & $\begin{array}{l}040310,040390, \\
040520,040610, \\
040620,040620, \\
040640,040690, \\
080510,080521, \\
080522,080550, \\
081210,081340, \\
160249,160553, \\
160556,160559\end{array}$ & 1.5 & 75 \\
\hline Part 3 & 25 & $\begin{array}{c}\text { Germany, Spain and the United } \\
\text { Kingdom }\end{array}$ & $\begin{array}{c}020329,040410, \\
040610,040690, \\
150910,150990 \\
200570\end{array}$ & 1.5 & 75 \\
\hline Part 4 & 25 & $\begin{array}{c}\text { Austria, Belgium, Croatia, Cyprus, } \\
\text { Czech Republic, Denmark, Estonia, } \\
\text { Finland, Germany, Greece, Hungary, } \\
\text { Ireland, Italy, Latvia, Lithuania, } \\
\text { Luxembourg, Malta, Netherlands, } \\
\text { Portugal, Romania, Slovakia, } \\
\text { Slovenia, Spain, Sweden and the } \\
\text { United Kingdon }\end{array}$ & $\begin{array}{l}040310,040510 \\
040630,040690, \\
081190,160100 \\
200860,200870 \\
200897,200989\end{array}$ & 1.5 & 75 \\
\hline
\end{tabular}




\begin{tabular}{|c|c|c|c|c|c|}
\hline $\begin{array}{l}\text { Section } \\
2\end{array}$ & $\begin{array}{c}\text { Tariff } \\
(\%)\end{array}$ & Affected countries & Affected products & EoS & ESE \\
\hline Part 5 & 25 & $\begin{array}{l}\text { Austria, Belgium, Bulgaria, Croatia, } \\
\text { Cyprus, Czech Republic, Denmark, } \\
\text { Estonia, Finland, France, Germany, } \\
\text { Greece, Hungary, Ireland, Italy, } \\
\text { Latvia, Lithuania, Luxembourg, Malta, } \\
\text { Netherlands, Poland, Portugal, Romania, } \\
\text { Slovakia, Slovenia, Spain, Sweden and } \\
\text { the United Kingdon }\end{array}$ & $\begin{array}{c}040520,040690 \\
160241,160242, \\
160249\end{array}$ & 1.5 & 75 \\
\hline Part 6 & 25 & $\begin{array}{l}\text { Austria, Belgium, Bulgaria, Croatia, } \\
\text { Cyprus, Czech Republic, Denmark, } \\
\text { Estonia, Finland, Germany, Greece, } \\
\text { Hungary, Ireland, Italy, Latvia, } \\
\text { Lithuania, Luxembourg, Malta, } \\
\text { Netherlands, Poland, Portugal, } \\
\text { Romania, Slovakia, Slovenia, Spain, } \\
\text { Sweden and the United Kingdon }\end{array}$ & $\begin{array}{c}040590,040630, \\
040640,040690, \\
160553,200799, \\
200840\end{array}$ & 1.5 & 75 \\
\hline Part 7 & 25 & $\begin{array}{l}\text { Austria, Belgium, Bulgaria, Croatia, } \\
\text { Cyprus, Czech Republic, Denmark, } \\
\text { Estonia, Germany, Greece, Hungary, } \\
\text { Ireland, Italy, Latvia, Lithuania, } \\
\text { Luxembourg, Malta, Netherlands, } \\
\text { Portugal, Romania, Slovakia, } \\
\text { Slovenia, Spain, Sweden and the } \\
\text { United Kingdon }\end{array}$ & 40690 & 1.5 & 75 \\
\hline Part 8 & 25 & $\begin{array}{l}\text { Austria, Belgium, Croatia, Cyprus, } \\
\text { Czech Republic, Denmark, Estonia, } \\
\text { Finland, Germany, Greece, Hungary, } \\
\text { Ireland, Italy, Latvia, Lithuania, } \\
\text { Luxembourg, Malta, Netherlands, } \\
\text { Poland, Portugal, Romania, Slovakia, } \\
\text { Slovenia, Spain, Sweden and the } \\
\text { United Kingdon }\end{array}$ & 40690 & 1.5 & 75 \\
\hline Part 9 & 25 & $\begin{array}{c}\text { Austria, Belgium, Bulgaria, Croatia, } \\
\text { Cyprus, Czech Republic, Denmark, } \\
\text { Estonia, Finland, Germany, Greece, } \\
\text { Hungary, Ireland, Italy, Latvia, } \\
\text { Luxembourg, Malta, Netherlands, } \\
\text { Poland, Portugal, Romania, Slovakia, } \\
\text { Slovenia, Spain, Sweden and the } \\
\text { United Kingdon } \\
\end{array}$ & 40690 & 1.5 & 75 \\
\hline Part 10 & 25 & $\begin{array}{c}\text { France, Germany, Spain and the } \\
\text { United Kingdom }\end{array}$ & $\begin{array}{l}071120,200570 \\
220421\end{array}$ & 1.5 & 75 \\
\hline Part 11 & 25 & Germany & $\begin{array}{l}090121,090122, \\
210111,820140, \\
820320,820330, \\
820340,820540, \\
821194,846719, \\
846880,846890 \\
851420,900211, \\
901310\end{array}$ & 1.5 & 75 \\
\hline
\end{tabular}




\begin{tabular}{|c|c|c|c|c|c|}
\hline $\begin{array}{l}\text { Section } \\
2\end{array}$ & $\underset{(\%)}{\text { Tariff }}$ & Affected countries & $\begin{array}{l}\text { Affected } \\
\text { products }\end{array}$ & EoS & ESE \\
\hline Part 12 & 25 & $\begin{array}{c}\text { Austria, Belgium, Bulgaria, Croatia, } \\
\text { Cyprus, Czech Republic, Estonia, } \\
\text { Finland, Germany, Greece, Hungary, } \\
\text { Ireland, Italy, Latvia, Lithuania, } \\
\text { Luxembourg, Malta, Netherlands, } \\
\text { Portugal, Romania, Slovakia, } \\
\text { Slovenia, Spain, Sweden and the } \\
\text { United Kingdon }\end{array}$ & 160249 & 1.5 & 75 \\
\hline Part 13 & 25 & Germany and the United Kingdon & $\begin{array}{c}190531,190532, \\
490110,490810, \\
491191,842952, \\
846729\end{array}$ & 1.5 & 75 \\
\hline Part 14 & 25 & $\begin{array}{l}\text { Germany, Ireland, Italy, Spain and the } \\
\text { United Kingdon }\end{array}$ & 220870 & 1.5 & 75 \\
\hline Part 15 & 25 & United Kingdon & $\begin{array}{l}220830,611011, \\
611012,611020, \\
611030,620299, \\
620311,620319, \\
620821,621112, \\
630130,630190, \\
630221 \\
\end{array}$ & 1.5 & 75 \\
\hline Part 16 & 25 & France and Germany & 821490 & 1.5 & 75 \\
\hline
\end{tabular}

